\title{
HESS Opinions: A conceptual framework for assessing socio-hydrological resilience under change
}

\author{
Feng Mao $^{1}$, Julian Clark ${ }^{1}$, Timothy Karpouzoglou ${ }^{2}$, Art Dewulf ${ }^{2}$, Wouter Buytaert ${ }^{3,4}$, and David Hannah ${ }^{1}$ \\ ${ }^{1}$ School of Geography, Earth and Environmental Sciences, University of Birmingham, Birmingham, UK \\ ${ }^{2}$ Public Administration and Policy Group, Wageningen University \& Research, Wageningen, the Netherlands \\ ${ }^{3}$ Department of Civil and Environmental Engineering, Imperial College London, London, UK \\ ${ }^{4}$ Grantham Institute - Climate Change and the Environment, Imperial College London, London, UK \\ Correspondence to: Feng Mao (f.mao@bham.ac.uk)
}

Received: 24 September 2016 - Discussion started: 19 October 2016

Revised: 21 May 2017 - Accepted: 30 May 2017 - Published: 20 July 2017

\begin{abstract}
Despite growing interest in resilience, there is still significant scope for increasing its conceptual clarity and practical relevance in socio-hydrological contexts: specifically, questions of how socio-hydrological systems respond to and cope with perturbations and how these connect to resilience remain unanswered. In this opinion paper, we propose a novel conceptual framework for understanding and assessing resilience in coupled socio-hydrological contexts, and encourage debate on the inter-connections between socio-hydrology and resilience. Taking a systems perspective, we argue that resilience is a set of systematic properties with three dimensions: absorptive, adaptive, and transformative, and contend that socio-hydrological systems can be viewed as various forms of human-water couplings, reflecting different aspects of these interactions. We propose a framework consisting of two parts. The first part addresses the identity of socio-hydrological resilience, answering questions such as "resilience of what in relation to what". We identify three existing framings of resilience for different types of human-water systems and subsystems, which have been used in different fields: (1) the water subsystem, highlighting hydrological resilience to anthropogenic hazards; (2) the human subsystem, foregrounding social resilience to hydrological hazards; and (3) the coupled human-water system, exhibiting socio-hydrological resilience. We argue that these three system types and resiliences afford new insights into the clarification and evaluation of different water management challenges. The first two types address hydrological and social states, while the third type emphasises the feedbacks and interactions between human and water compo-
\end{abstract}

nents within complex systems subject to internal or external disturbances. In the second part, we focus on resilience management and develop the notion of the "resilience canvas", a novel heuristic device to identify possible pathways and to facilitate the design of bespoke strategies for enhancing resilience in the socio-hydrological context. The resilience canvas is constructed by combining absorptive and adaptive capacities as two axes. At the corners of the resulting twodimensional space are four quadrants which we conceptualise as representing resilient, vulnerable, susceptible, and resistant system states. To address projected change-induced uncertainties, we recommend that efforts now be focused on shifting socio-hydrological systems from resistant towards resilient status. In sum, the novel framework proposed here clarifies the ambiguity inherent in socio-hydrological resilience, and provides a viable basis for further theoretical and practical development.

\section{Introduction}

There is now great interest in understanding human-water relationships from a complexity perspective. One example is the field of "hydro-sociology" (Linton and Budds, 2014; Sivakumar, 2012), emphasising social scientific and humanities approaches to understanding the interactions between humans and water. Similarly, Sivapalan et al. (2012, 2014) have foregrounded the human role in the water cycle by establishing "socio-hydrology" as a perspective to understand modification and changing patterns of water use in the An- 
thropocene. While presenting hydrological complexity from different viewpoints, both approaches highlight the interrelationship of human and water systems as one prone to instability. Shifting hazard regimes and altering external conditions caused by human-induced change means dealing with uncertainties, and the prospect of system degradation to undesired states and/or collapse. This opens up questions of how socio-hydrological systems respond to perturbations and future management uncertainties, making it an opportune time to explore the concept of resilience in socio-hydrological contexts.

Since its introduction in the 1970s, the idea of resilience has evolved from a descriptive notion to a normative concept with broad and often ambiguous meanings (Brand and Jax, 2007; Olsson et al., 2015; Weichselgartner and Kelman, 2015). Some authors have observed that this lack of conceptual clarity hinders the application of resilience thinking (Strunz, 2012), raising questions of how to apply the concept to socio-hydrological systems. In the coupled humanwater context, resilience is now used in many different ways, such as hydrological resilience, aquatic ecological resilience, community and urban resilience to hydrological disasters, and resilience of water cycles (Rockström et al., 2014). Yet these applications do not always capture the essence of sociohydrological dynamics or lend support to inter-disciplinary resilience research. We argue that this is because of our limited understanding of human-water couplings and hence the type of resilience that adheres to systems, as much as it is a product of lack of clarity in analysing systematic change. As a result, system identities need defining before examination is undertaken of their intrinsic resilience types (Cumming et al., 2005).

Our aim here is to propose a conceptual framework for assessing resilience in socio-hydrological contexts, and by which we provide opinions for understanding and managing socio-hydrological resilience. Instead of offering a single prescriptive solution, this framework supports pluralist perspectives and encourages debate on socio-hydrology and its interrelations with resilience. The paper's structure is as follows. In Sect. 2, we examine the relationship between resilience, system type and capacities, and characterise resilience as a set of absorptive, adaptive, and transformative properties of the system. In Sect. 3, we classify three types of human-water couplings and their associated resilience forms. Within this classification, we propose studying sociohydrological resilience, and explain how this differs from the existing notions of hydrological and social resilience. We also show how different resilience capacities arise in each human-water coupling type. We proceed to argue that sociohydrological systems and subsystems and their attendant resilience dynamics can be characterised using the conceptual toolkit of ecosystem services, as this approach effectively classifies dominant processes of human-water interactions already. In Sect. 4, we show how to implement the new concept of socio-hydrological resilience. To do so, we develop the notion of a "resilience canvas" to specify pathways toward particular socio-hydrological resilience states. We analyse the role of different resilience capacities in water management under change, and identify fields of further enquiry. Our overall conclusion is that to enhance system capacity to face future uncertainties requires a concerted shift away from resistance to resilient water management.

\section{Resilience, systems, and capacities}

The concept of resilience has many definitions, and is routinely used in multiple fields in widely contrasting contexts (Brand and Jax, 2007). Our aim here is not to focus on this variety, but instead to characterise how resilience is interpreted in order to clarify its relationship to other concepts, especially systemic capacities and properties (Anderies et al., 2004; Klein et al., 2003; Plummer and Armitage, 2007). Resilience is usually defined as the capacity of a system to absorb disturbance without substantially challenging its function or structure (Walker et al., 2004). In a more generalised definition, resilience is "the capacity to persist in the face of change, to continue to develop with ever changing environments" (Folke, 2016, p. 2). Thus, this concept is understood as a set of systemic absorptive, adaptive, and transformative capacities, which offers scope for its conceptualisation in three dimensions - persistence for now, and response for future contingencies in incremental or in radical ways (Béné et al., 2014; Miller et al., 2011). A clear understanding of the overall system is thus an essential precursor to any evaluation of its resilience, since it determines what the identity or subject of resilience is (Carpenter et al., 2001; Evans and Reid, 2013). A system refers to a set of interacting components forming a complex whole, which is delineated by its boundaries, surrounded by its environment, and characterised by its structure and functions (Backlund, 2000; Limburg et al., 2002). However, many socio-hydrological systems have ambiguous boundaries, making it difficult to examine resilience. So, for example, referring to "the system" may mean components or parts of the whole human-water interaction, such as the water subsystem with anthropogenic drivers, or to the human subsystem with hydrological drivers, or to the sociohydrological system, which emphasises the feedbacks and interactions between human and water processes in a balanced and integrated perspective.

Once the system type or the resilience identity is defined, it helps to answer a series of essential questions that sustain the clarity of the resilience concept and application in sociohydrological contexts: for example, what aspects of systems are being examined, what key indicators of system state need to be established, what possible desired state is sought, and ultimately what shapes the resilience process (Carpenter et al., 2001; Mao and Richards, 2012). Resilience in this context is mainly driven by two factors - hazards and external conditions, often referred to as "fast" and "slow" vari- 

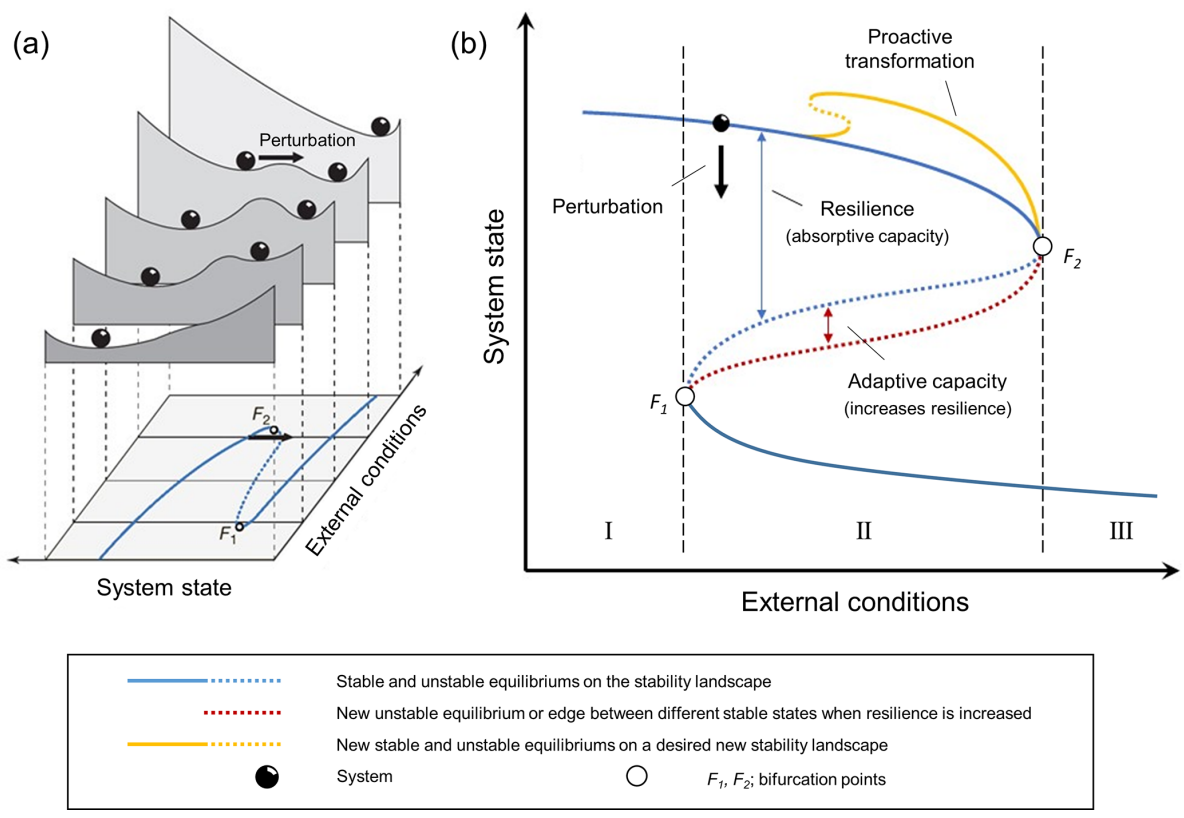

Figure 1. Bifurcation diagrams for socio-hydrological resilience: (a) stability landscape changes along with external conditions, adapted from Scheffer et al. (2001); (b) Bifurcation diagram illustrating absorptive, adaptive, and transformative capacities. The two dashed lines across $F_{1}$ and $F_{2}$ divide the bifurcation process into three phases. Phase I and III have only one stable equilibrium, while Phase II has two stable equilibriums. Perturbations in Phase II may drive the system from one stable state to another. Absorptive capacity refers to the original meaning of resilience; adaptive capacity refers to the capability to increase resilience in response to external change (red line); transformative capacity refers to the capacity to respond more radically, such as through proactively navigating the system to a desired new stability landscape (yellow line). Panel (a) is adapted with permission from Macmillan Publishers Ltd: Nature Vol. 413 Issue 6856, Scheffer et al., copyright 2001 .

ables (Walker et al., 2012). Hazards are threats to a system, usually comprising occasional, recurrent, and continuous perturbations (Gómez-Baggethun et al., 2012; Kuo et al., 2012; Turner et al., 2003) such as diffuse pollution, land-use change, drought, and flooding. External conditions or controlling variables include changing climate altering the influence of legal and socio-cultural contexts and the role of science and technology on the stability landscape which is used here as a metaphor to describe the resilient process of systems (see Dent et al., 2002; Scheffer et al., 2001). Systems can shift from one position to another, which can result in large, abrupt, long-lasting changes to their structure and function (Biggs et al., 2009). Resilience management seeks both to reduce hazards to prevent the system shifting to an undesirable position (e.g. degradation of ecosystems and living standards) and to move the system toward a desired position. The stability landscape itself can also alter because of change in slow variables. This resilience process is usually represented as a bifurcation diagram, showing the system state as a ball moving between equilibrium positions (Scheffer et al., 2001; see Fig. 1).

Thinking through how absorptive, adaptive, and transformative capacities feature in these diagrams opens up new possibilities for understanding systematic and resilience properties (Walker et al., 2004, 2009). Based on Fig. 1a, the interrelation between three resilience capacities is portrayed in Fig. 1b. Absorptive capacity equates to the original concept of resilience: that is, the capacity of absorbing disturbance while retaining essential structures and functions (Cumming et al., 2005; Holling, 1973; Walker et al., 2004). It is represented as the size (e.g. width) of the equilibrium region (Walker et al., 2004). This capacity is closely connected with the notion of sensitivity (McGlade et al., 2008; Yan and $\mathrm{Xu}, 2010$ ). Adaptive capacity is usually defined as the systemic capability to respond to perturbation from a changing environment through adjustment and alteration. If absorptive capacity describes system tolerance to change in structure and function under existing conditions, then adaptive capacity denotes how much this absorptivity can increase in response to external change and to change-induced uncertainties in the future (Engle, 2011; Gallopín, 2006; Smit and Wandel, 2006). It also determines resilience by moving the tipping point and making the desired attraction basins wider or deeper, although it does not necessarily lead to improved system state (Walker et al., 2004, see red dotted line in Fig. 1b). Lastly transformative capacity, or transformability, also refers to the ability to respond, but in a more radical way. This is a capacity to change the stability landscape or even create a new system by means such as introducing new components or new ways of living, when existing eco- 
logical, economic, or social structures are untenable (Folke et al., 2010; Walker et al., 2004). Transformations aim to navigate the systematic transitions from an undesired stability landscape to a new, desired state (Folke et al., 2010, see Fig. 1b; Walker et al., 2009). Proactive transformation may be attempted if change in external conditions is so great that incremental improvement through adaptive capacity is inadequate to meet managerial goals (Béné et al., 2014; Ernstson et al., 2010).

\section{A typology of human-water couplings and resilience framings}

The importance of using resilience in the coupled humanwater context is increasingly evident in both academic and public policy fields, ranging from aquatic ecosystem conservation (Khamis et al., 2013; Sala et al., 2000) to hydrological risk management (Adger et al., 2005; Hallegatte et al., 2013) and sustainable water use and development (Pahl-Wostl et al., 2013; Vorosmarty et al., 2000). For the reasons explained already, it is critical to clarify the character of resilience in socio-hydrological contexts which in turn is determined by the human-water coupling type. Hence, we identify three types of human-water couplings with their own resilience framings: (1) the water subsystem, with hydrological resilience to anthropogenic hazards; (2) the human subsystem, with social resilience to hydrological hazards; and (3) the socio-hydrological system, with socio-hydrological resilience (Fig. 2). We therefore argue that socio-hydrological resilience should refer to resilience of socio-hydrological systems as a whole, which is one specific type of resilience in socio-hydrological contexts. These three types represent different perspectives from which to approach and understand socio-hydrological systems and human-water interactions, whilst emphasising that humans and water are fundamentally interrelated. The former two types focus on intrinsic hazard-subsystem relations, while the latter covers these subsystem relations and the broader and more iterative interplay between them. Here, it is worth noting that socio-hydrology and hydro-sociology have close connections (Sivakumar, 2012), but different emphases (Wesselink et al., 2016). Here we adopt Sivapalan's interpretation of socio-hydrology which has as its focus the coevolution and feedbacks of coupled human-water systems (Sivapalan et al., 2012). Thus these three types of coupling encapsulate how different fields (e.g. conservation, disaster management, and water resources management) deal with human-water couplings, rather than normative expectations of what people should (or should not) do. In the following subsections, features such as resilience subjects, desired system states, indicators, and application fields are examined for each type of resilience framing (Table 1).

\subsection{Water subsystem with anthropogenic hazards}

Resilience was advanced initially as a phenomenon of freshwater ecosystems to explain the dramatic change in aquatic ecosystems precipitated by anthropogenic disturbance (Table 1), such as algal blooms caused by nutrient enrichment and fish population collapses triggered by overharvesting (Holling, 1973). Based on these cases, this type of coupling describes a particular aspect of human-water interactions, which focuses on water subsystems and external anthropogenic factors shaping water subsystems. However, from this perspective the human subsystem and its attendant hydrological hazards are not the main emphasis.

Resilience has since been used in many water subsystems, such as lakes, rivers, and oceans (Dudgeon et al., 2006; e.g. Gibbs, 2009; Hoegh-Guldberg et al., 2008; Willis et al., 2010), where hydrological conditions can be measured by surrogate indicators (e.g. Holling, 1973) or through examining other biotic or abiotic components. This coupling model is primarily used in aquatic ecosystem conservation and management, where the goal is to maintain subsystem equilibrium or restore it to a desired historical state. Climate change or increased human hazards may degrade aquatic ecosystems or propel them to irreversible undesired end states (O'Reilly et al., 2003; Sala et al., 2000), prompting a need to consider options for resilient water management (Mace, 2014). For example, climate change and ocean acidification together with local anthropogenic stress decrease sea water quality, alter community structure and diversity, change species distribution, and might even push ecosystems such as coral reef to functional collapse (Carpenter et al., 2008; Doney et al., 2012; Hoegh-Guldberg and Bruno, 2010). In such cases, aquatic organisms (e.g. macroinvertebrates and macrophytes) can be used for biological monitoring to assess adverse human impacts on species and ecosystems (e.g. Miller et al., 2007; Ozkan et al., 2010). Ecological indicators have been developed for river basin management in many regions of the world (Bunn et al., 2010; Josefsson and Baaner, 2011). Attention has also been paid to the resilience of hydrological aspects of water systems under climate change, extreme weather and alteration in land cover (Harder et al., 2015; Peterson et al., 2012). Better understanding of multiple steady hydrological states and the process interaction of switching between states can inform adaptive water management (Botter et al., 2013).

Absorptive capacity of water subsystems is mainly from essential ecosystem and hydrological processes. The adaptive dimension of hydrological resilience usually comes from a diversity of species, habitats, or landscapes. From a biophysical viewpoint, adaptation refers to the response of organisms to their environment on the genetic, individual, and/or ecosystem scale (Engle, 2011; Hoffmann and Sgrò, 2011; Krimbas, 2004). This underlies redundancy and natural selection, which drives evolution (Krimbas, 2004; Lindner et al., 2010). However, the improvement of hydrological 
(a)

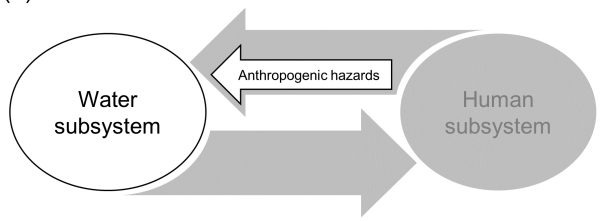

(b)

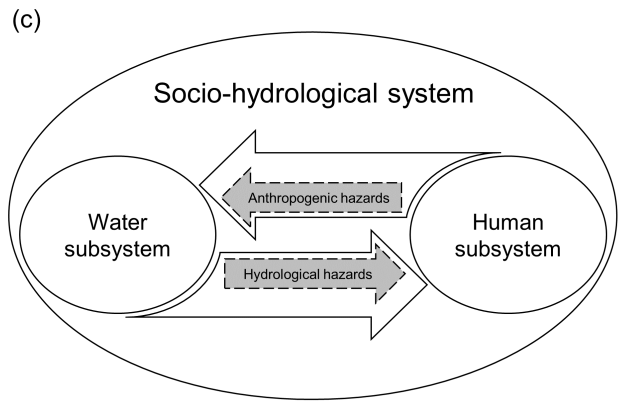

Figure 2. Schematic diagram of three human-water coupling types, each foregrounding different aspects of the socio-hydrological system. (a) Water subsystem with anthropogenic hazards, where the human subsystem, water impacts on human subsystem, or other forms of human impacts on the water subsystem are not the main focus. (b) Human subsystem with hydrological hazards, where, similarly to the water subsystem, human impacts on water subsystem or other forms of water impact on the water subsystem are not emphasised. (c) Sociohydrological system with water and human subsystems and anthropogenic and hydrological hazards as two of many forms of human-water interactions.

Table 1. A comparison of three types of human-water couplings and resilience framings.

\begin{tabular}{|c|c|c|c|}
\hline $\begin{array}{l}\text { Human-water } \\
\text { coupling types }\end{array}$ & $\begin{array}{l}\text { Water subsystem with anthro- } \\
\text { pogenic hazards }\end{array}$ & $\begin{array}{l}\text { Human subsystem with hydrologi- } \\
\text { cal hazards }\end{array}$ & Socio-hydrological system \\
\hline System & Water subsystem & Human subsystem & Socio-hydrological system \\
\hline $\begin{array}{l}\text { Desired system } \\
\text { state }\end{array}$ & $\begin{array}{l}\text { e.g. High "naturalness" or historical } \\
\text { state }\end{array}$ & $\begin{array}{l}\text { e.g. Social prosperity, development } \\
\text { and justice }\end{array}$ & $\begin{array}{l}\text { e.g. System integrity, and healthy } \\
\text { human-water relationship }\end{array}$ \\
\hline System indicator & $\begin{array}{l}\text { Biotic and abiotic indicators, such } \\
\text { as aquatic ecological composition, } \\
\text { biodiversity, and flow regime }\end{array}$ & $\begin{array}{l}\text { e.g. Social, economic, institutional, } \\
\text { physical aspects of human societies }\end{array}$ & $\begin{array}{l}\text { e.g. Compositional indicator and } \\
\text { human-water relationship }\end{array}$ \\
\hline Resilience & $\begin{array}{l}\text { e.g. Hydrological resilience and } \\
\text { hydro-ecological resilience }\end{array}$ & e.g. Social resilience & Socio-hydrological resilience \\
\hline Hazards & Anthropogenic hazards & Hydrological hazards & $\begin{array}{l}\text { Internal and external, anthro- } \\
\text { pogenic, and hydrological hazards }\end{array}$ \\
\hline Application fields & $\begin{array}{l}\text { e.g. Water conservation and restora- } \\
\text { tion }\end{array}$ & e.g. Disaster management & $\begin{array}{l}\text { e.g. Water resources and ecosystem } \\
\text { services management }\end{array}$ \\
\hline
\end{tabular}

adaptive capacity does not exclude anthropogenic contributions, and can be achieved by restoring the biodiversity and integrity of aquatic ecosystems. Transformative capacity is seldom used in this water-subsystem-centred type, because the idea of creating an entirely new system is inconsistent with the philosophy of conservation, which focuses on maintaining the natural world.

\subsection{Human subsystem with hydrological hazards}

The second type of coupling is the human subsystem with hydrological hazards (Table 1). Here hydrological components are not considered as a system, but as adverse impacts on human well-being. Although hydrological hazard may be caused or increased by human activities, or its impacts on human society may be exacerbated by inadequate management or responses (Van Loon et al., 2016), emphasis on re- 
silience from this perspective is on how hydrological hazards affect human subsystems and how human societies respond to these hazards, rather than how water subsystems are changed by human activities. This human-hydrological coupling is commonly applied in disaster management (Kelman et al., 2015; Sudmeier-Rieux, 2014), where resilience is derived from capacity-building within human systems to better cope with more frequent hydrological shocks (for example, those induced by climate change; Adger et al., 2005; Aerts et al., 2014).

Human subsystems have many facets and their state is described through numerous indicators and disciplinary approaches. Similarly, resilience understandings vary widely. Meerow et al. (2016) describe human subsystems as complex arrangements of processes and phenomena at many different scales and levels. Reviewing 675 articles on resilience, Ostadtaghizadeh et al. (2015) identify five main domains of human subsystems, comprised of social, economic, institutional, physical, and natural categories. For example, hydrological hazards may cause injuries, death, and property and infrastructure loss (Liao, 2012), which can be quantified to estimate the approximate cost of disasters (Keating et al., 2015). Apart from this physical aspect, socio-economic condition can also be used to capture the degree of resilience of human systems to hydrological impacts, with economic growth, incomes and livelihoods often used as proxies (Kumar, 2015; Plummer and Armitage, 2007).

Resilience of human systems is usually evaluated from social science perspectives (Lorenz, 2013; Olsson et al., 2015), through concepts such as social capital and network structures, institutions, and power relations. Knowledge and discourses have received increased attention (Keck and Sakdapolrak, 2013; Wyborn, 2015). Cutter et al. (2008, 2010) highlight "community competence" as capacities to understand risks, promote individual physical and emotional health (Norris et al., 2008), and maintain cultural norms such as livelihood practices and social institutions (Crane, 2010). Indeed, recent studies highlight that an alternative approach to engage with challenges posed by resilience is to use a more theoretically pluralist perspective that enhances engagement and utilisation of insights from different angles, alongside insights gained from resilience scholarship (Karpouzoglou et al., 2016a).

Consequently, resilience from the perspective of managing human subsystems tends to emphasise particular societal expectations in relation to how to deal more holistically with hydrological hazards. If social aspects of human subsystems are also considered, more anticipatory targets can be discerned. However, critics of resilience have argued that there is still significant scope for developing a more nuanced understanding of resilience and how it relates to society. Cote and Nightingale (2012) argue that there is still far less attention paid to normative and epistemological questions. For example, the policy use of resilience is often normative in the sense that it implies that resilience is always something "good" to be strived for. However, the tendency to see resilience as being an objectively defined desirable can create challenges for social scientists working with the concept (Olsson et al., 2015). An important point is that questions that relate to the power and politics of both how and who gets to define resilience need to be brought into the foreground of resilience research, otherwise resilience runs the risk of becoming a power-blind concept (Davoudi et al., 2012). A similar point is made by MacKinnon and Derickson (2012) in arguing that resilience as a concept is too conservative in outlook, because it embraces contemporary societal expectations rather than challenging them; they go further by advocating a shift from resilience to resourcefulness as a concept that better matches the aims of emancipatory social sciences. West et al. (2014) have argued that some of the criticisms around resilience can be overcome through identifying better ways for researchers from social and natural science backgrounds to open new dialogues, so establishing common ground while identifying areas of disagreement.

In this type of framing, absorptive capacity is the ability to defend from hydrological hazards, while social adaptive capacity is a means to improve this ability and reduce the vulnerability of human subsystems including individuals, communities, groups, and institutions in coping with water related shocks and changes (Bennett et al., 2014). Gupta et al. (2010) reviewed the existing literature and summarise six dimensions of adaptive capacity: variety and diversity of problem framing and solving, learning capacity, room for autonomous change, leadership, resources, and fair governance. A similar conclusion is made by Bennett et al. (2014) in their four categories of adaptive capacity, which include flexibility and diversity, the capacity to organise, learning and knowledge, and access to assets. Besides incremental improvements, human subsystems can even radically reorganise communities and proactively transform into entirely new settings under global change. An extreme example is climatechange-induced migration; here, the subject of resilience under contingent hydrological impacts (populations at-risk) may abandon settlements, migrate to new locations, and restructure human subsystems (Methmann and Oels, 2015).

\subsection{Socio-hydrological system and its resilience}

While it is possible to examine resilience from the perspective of water or human subsystems, we argue that it can also be considered in relation to coupled socio-hydrological systems within which human and water subsystems are constitutive elements. This move to socio-hydrology as a framing device implies the need to reassess resilience from a coevolving viewpoint, where water and human systems make and remake each other and are interdependent in time and space (Sivapalan et al., 2012), so implicating water and society in governance arrangements (Sivakumar, 2012). Here it is the state of the coupled system rather than a particular perspective of either water or human systems that is of interest. 
This third type of coupling foregrounds the states, conditions, and interactions of coupled human and water subsystems to build a more balanced understanding of their process interrelationships, and highlights resilience of socio-hydrological systems to both internal and external hazards.

As discussed in the previous section, desired states of the water subsystem are usually high "naturalness" or historical conditions measured by biotic and abiotic indicators, while desired states of the human subsystem are more normative societal expectations set by relevant social groups. However, it is a challenge to define the current state as well as the desired state of this coupling type of human-water system, which helps to clarify the identity of socio-hydrological resilience and to answer "resilience of what". A conventional approach to evaluate coupled systems is to use compositional indicators (Meerow et al., 2016). Components from subsystems are assessed separately and then summed up to obtain a proxy value for the overall coupled system state. For example, a disaster resilience index usually regards the overall system as a comprised of constitutive ecosystem and human subsystem domains (i.e. social, economic, institutional, and physical; Ostadtaghizadeh et al., 2015). However, if used in the socio-hydrological context, this compositional approach cannot gauge the complex interactions and feedbacks of human-water coupling (Montanari et al., 2013). Instead, measures are needed that model the dynamic interdependencies of continually interacting components (Gao et al., 2016). This demands a direct assessment of the coupled system using indicators or measures that depict multi-directional interactions. Examples include human benefits from hydrological systems, water-resource use, water-supported socioeconomic development, governance over water, and societal and behavioural response to hydrological hazards (Carey et al., 2014; Elshafei et al., 2014). We argue that the notion of hydrological ecosystem services, which attempt to bridge the two subsystems, is a promising framework to describe the socio-hydrological state and to be incorporated into the resilience thinking (Biggs et al., 2012, 2015; Engel and Schaefer, 2013). In effect, the level of ecosystem services provision is the product of conflicting factors from both sides, such as human demand and ecosystem supply, human disturbances and ecosystem regulation and regeneration, and human management and water resources.

The possibility that hydrological ecosystem services offer a good proxy of human-water intersections is also reflected by its normative goals. Thus, high ecosystem service provision implicitly requires integration of at least three components. First is healthy biophysical systems. Robust ecosystem structure, processes, and functioning are necessary preconditions for the sustainable provision of ecosystem services (de Groot et al., 2002). Second is the intrinsic value of biophysical systems to human society, even if the value does not have a direct use (Pearson, 2016). Third is the range of established routeways in human societies to channel benefits from nature. This implies that using ecosystem services to measure the state of socio-hydrological systems not only reflects the naturalness of the hydrological system, but also human preferences for the resulting coupled system (Dufour and Piégay, 2009). So a continuing supply of ecosystem services does not necessarily mean ecosystems are pristine or close to a "natural" condition, but instead reflects the dependence of the human subsystem to select for particular services (National Research Council, 2013; Zedler, 2000). Ecosystem management thus improves the resilience of ecosystems by deliberate human interventions to achieve a desired level of ecosystem services of a preferred sort.

According to the Millennium Ecosystem Assessment (2005), each water ecosystem provides multiple benefits to human society, including (1) providing services such as water, aquatic products, and hydropower; (2) regulating services including water purification and flood and climate regulation; and (3) cultural services or nonmaterial benefits obtained from aesthetic or spiritual enrichment, recreation, scientific research, and educational activities. Vigerstol and Aukema (2011) identify four processes that produce water-related ecosystem services - water retention, water yield, natural water filtration, and water quality purification. Terrado et al. (2014) specify four hydrological ecosystem services vulnerable to climate extremes drinking water, hydropower production, nutrient retention, and erosion control. Fisheries and products from aquatic ecosystems are essential for human societies but also subject to change, and need to be sustainable and resilient (Barange et al., 2014). Ecosystem services as a framework therefore link the human and water system, while being a viable basis for decision and policymaking (Brauman et al., 2007; Daily et al., 2009). Thus, managing socio-hydrological resilience can be understood as regulating and enhancing the resilience of ecosystem services that support livelihoods and human needs for protection from natural hazards, making it a viable proxy for socio-hydrological systems.

Resilience of a socio-hydrological system may not only come from its water or human subsystems, but from humanwater interactions that are not prominent in the first two types. For example, real-time monitoring of hydrological disasters contributes to absorptive capacity. Adaptive capacity can be underpinned by water governance and institutions, as well as environmental knowledge learning and exchange. Transformative capacity may be rooted in the incentive, ability, and innovation in optimisation of water usage model, development of water-dependent socio-economic structure, and reconstruction of human-water relations through resettlement (Arnall, 2015; Barrett and Constas, 2014; Wilson et al., 2013). Identifying and analysing the sources of capacities helps to design resilience-building strategies for sociohydrological systems in a more comprehensive way, without missing valuable improvement possibilities. 


\section{Pathways to resilience in the socio-hydrological context}

Building on the preceding section, here we conceptualise resilience in the socio-hydrological context as a normative goal that can be achieved through human intervention.

\subsection{Resilience capacities and the resilience canvas}

Building resilience requires not only improvement of the absorptive capacity to resist existing hazards, but also enhancement of system resilience to cope with future uncertainties. This is where the properties of adaptive and transformative capacity advanced here enrich the socio-hydrological perspective. By conceptualising resilience this way, represented by increased adaptive and transformative capacities, the need for incremental adjustment or radical improvement of systematic states becomes clearer.

An analogy can be drawn with conservation ecology. Gillson et al. (2013) use two axes of concerns (landscape vulnerability and conservation capacity) to design conservation strategy. Based on this approach, here we introduce the resilience canvas by combining two of the constitutive capacities as the $x$ and $y$ axes (Fig. 3). This section demonstrates how the resilience canvas can be constructed and applied, by emphasising the first two dimensions of resilience - absorptive capacity for current hazards and adaptive capacity for future contingencies. The transformative capacity is not focused on in the discussion because it requires some further exploration compared to the first two capacities - there is still an ongoing debate on what exact systematic attributes are needed to support a radical transformation to an entirely new stage (Robinson and Carson, 2015; Wilson et al., 2013). Here we keep the analysis of resilience capacities in a visually simple way as a two-dimensional space instead of a "resilience cube", and select the first two capacities for demonstration purposes.

Four resulting system states are found at the corners of the canvas: most resilient (top-right: high absorptive and high adaptive), vulnerable (bottom-left: low absorptive and low adaptive), susceptible (top-left: low absorptive and high adaptive), and resistant (bottom-right: high absorptive and low adaptive). These four quadrants are not static, and systems can move between them via structured management interventions over time, which we term "pathways". A resilient-vulnerable gradient from top-right to bottom-left is shown on the canvas (Fig. 3).

\subsection{Building pathways to resilience in socio-hydrological contexts}

The pathways on the resilience canvas represent a series of three hypothesised human intervention scenarios introduced to effect system change (see Haasnoot et al., 2013; See also Fig. 3). These are hypothesised in the sense that in adopting

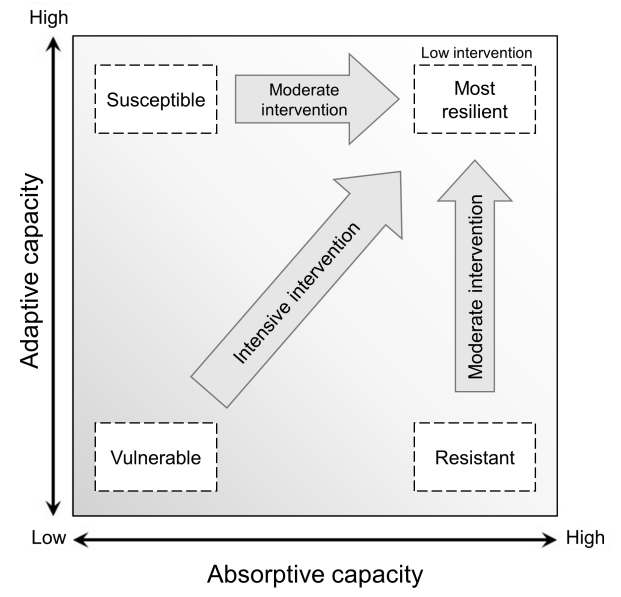

Figure 3. "Resilience canvas" with absorptive and adaptive capacities as two axes, showing resilient-vulnerable gradient, resilience conditions, and pathways to resilience. The four dashed rectangles illustrate resilient, resistant, susceptible, and vulnerable system conditions. The grey arrows represent pathways, or a series of concerted interventions designed to drive systems from one condition to another.

a broad definition of resilience, these pathways could be very different depending on the social actors and hydro-social context of operation. However, for the purposes of illustrating how the pathways approach could be useful in the case of the resilience canvas, pathways help steer socio-hydrological systems towards the "most resilient" status (i.e. top-right of the canvas). This is regarded for the purposes of this study as the most valued water management goal.

Susceptible socio-hydrological systems can be strengthened by increasing absorptive capacity and by making hydrological ecosystem services supply more robust and sustainable under current hazard regimes. For example, water pollution may decrease potable water availability, while introducing vegetated buffer zones can protect water quality (Hickey and Doran, 2004; Khamis et al., 2013); aquatic ecosystem degradation may shrink fish populations and food yield from aquatic products, and diversifying abiotic characteristics such as habitat supports the resilience of faunal populations (Bisson et al., 2009; Khamis et al., 2013). Hydrological disasters also deplete human benefits derived from water systems, and setting up early-warning systems can substantially increase the capabilities to deal with disasters (Adger et al., 2005).

By contrast, for resistant systems, approaches are needed that improve system adaptability and capability to cope with future disturbance. Adaptive capacity can be enhanced in several ways. One approach is to restore the essential ecosystem processes that generate services. For example, hydrological adaptive capacity depends on various intrinsic factors such as biomass, biodiversity, and the ecological traits of species (Dawson et al., 2011; van Vliet et al., 2013). In 
an abiotic context, adaptive capacity can also be determined by features such as high river connectivity (Khamis et al., 2013), stable hydrological cycles (Thomas, 2016), and heterogeneous landscape (Czucz et al., 2011). A second approach is to raise social and institutional capabilities, such as accessibility to information and resources (Milman and Short, 2008), responsiveness to environmental change (Malhotra et al., 2007), enhanced institutional structure and governance processes (Folke et al., 2005; da Silveira and Richards, 2013), boosted stakeholder participation (Few et al., 2007), and encouragement of learning and knowledge dissemination and exchange (Pahl-Wostl, 2009).

Although pathways can be constructed for the four system states, factors that improve different capacities via different capacity sources (i.e. ecological-hydrological, social, or human-water interaction) cannot always be distinguished or promoted independently. For example, maintaining diversity and redundancy of system components such as species, landscape types, knowledge systems, actors, cultural groups, and institutions benefits systematic resilience in various ways; so managing connectivity not only facilitates system recovery, but also improves the responsive capability to future uncertainties (Biggs et al., 2012, 2015). These activities are applicable for both social and natural sciences and cut across the three socio-hydrological resilience capacities.

Scheffer et al. (2015, p. 1317) suggest keeping systems within the "safe operating space" by managing down local stressors (fast variables) to a low value and responding to future climate projections (slow variables). The resilience canvas portrays this management strategy from the perspective of preparedness instead of driving variables. The impact of local stressors as well as climate change can be better mitigated with increasing absorptive and adaptive capacity, respectively. It implies that socio-hydrological systems should not only be kept within predetermined operating limits but also be the focus of bespoke resilient strategies. Khamis et al. (2013) compare the network sensitivity and conservation capacity of two catchments - the Taillon-Gabiétous catchment in the French Pyrénées and the Rhône catchment in the Swiss Alps - by assessing nine variables. It was found that the Rhône catchment has relatively higher absorptive capacity because of its lower network sensitivity, lower potential for alien-species invasion, and higher cryosphere-flow buffering, while the Taillon-Gabiétous catchment has higher adaptive capacity due to its larger proportion of conservation area and higher naturalness of river flow. Overall, the two catchments have a similar evaluation of resilience for their similar distance to the most resilient stage on the resilience canvas (Fig. 4). However, customised strategies should be developed for each catchment to achieve the resilient goal.

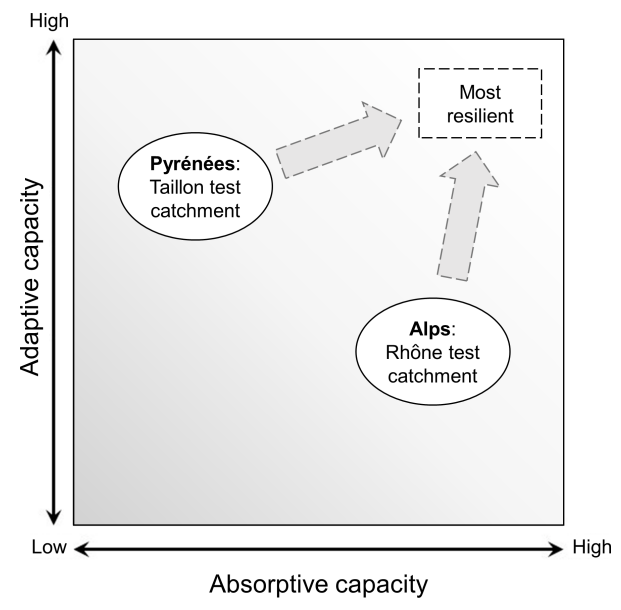

Figure 4. Regional comparisons of hydrological resilience. Two test catchments are compared, including the Taillon-Gabiétous catchment in the French Pyrénées and the Rhône catchment in the Swiss Alps.

\subsection{Resilience trajectory of global socio-hydrological systems}

The resilience canvas can be used on scales from the river basin to the global. By analysing our preparedness to cope with local stressors and change, the resilience canvas illustrates a development trajectory for global socio-hydrological systems (Fig. 5). This section suggests that pathways are not always in straight lines, while the constitutive capacities of resilience do not usually grow equally while the overall resilience is increasing. It also shows the potential to shift from resistant to resilient water management strategies, and on this basis, identifies attendant future research and implementation gaps.

The development phases of global human-water relations are identified and discussed in the literature. Mace (2014) for example argues that we are experiencing a shift in emphasis from "Nature suffering from People" or "People benefiting from Nature" to "People and Nature" as a more interdisciplinary and interactive framing for conservation purposes. Gleick et al. (2009) and Gleick and MacDonald (2010) also identify three water eras characterised by contrasting water challenges and problems as follows: nature's water resources; intensively manipulating water sources; and massive global crisis, a stage demanding interdisciplinary and integrated approaches for management purposes. By examining the history of the Murrumbidgee River basin, Australia, Kandasamy et al. (2014) recognise four main development eras of socio-hydrological systems: building irrigation and associated infrastructure, gradual appearance of environmental degradation, awareness of environmental impacts and application of consensus strategies, and switching to a directed government interventionist strategy. There is a lagging societal and governmental response to environmental change 


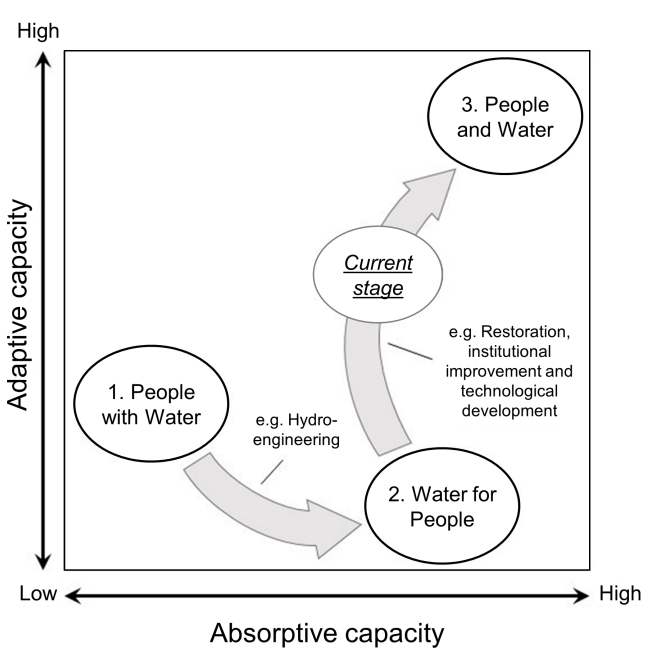

Figure 5. Global development of socio-hydrological resilience on the "resilience canvas". Three main developmental stages are (1) People with Water, (2) Water for People, and (3) People and Water. The current global socio-hydrological system has been moving from the second to the third stage.

during the development - it can take years to become aware of the side-effects of infrastructure construction and to test and perform the remedial measures until they have an effect. Kandasamy et al. (2014) described this changing attitude in respect of the environment as a "pendulum swing" - the balance point in water allocations is turning around between humans and ecosystems. Along with the development of socio-hydrological systems, their resilience changes and evolves simultaneously. Therefore, based on these classifications, three main stages of socio-hydrological resilience on the global scale are summarised and presented on the resilience canvas (Fig. 5).

1. People with Water. Before intensive modification of environments, human societies mainly relied on natural hydrological cycles for subsistence (e.g. huntinggathering) and to support extensive low-productivity agriculture reliant on limited control of the water subsystem (Gleick, 2009). The ecosystem services were often vulnerable to internal or external hazards, such as water-related diseases and adverse hydrological events, because of insufficient physical and institutional preparedness. However, the unoptimised ecosystem services did not cause too many problems, because of the small and dispersed population and low demand on hydrological ecosystem services (Gleick, 2009). Therefore, at this stage, absorptive capacity was low and adaptability was mainly provided by the naturalness of ecosystems.

2. Water for People. As the population has grown and socio-economic development risen, ecosystem services obtained by human societies from water systems have no longer proved sufficient. New technologies and approaches were invented to intentionally manipulate water cycles to meet new societal demands (Gleick, 2009). Along with the development of hydraulic engineering, humans have dramatically increased the range of ecosystem services obtained from water subsystems, such as hydropower, water availability, flood regulation, and more intensive forms of food production. This development of socio-hydrological systems explicitly emphasised the benefits people received from water, and marks a transition to a "Water for People" framing (Mace, 2014).

The resilience of socio-hydrological systems was also altered according to prevailing socio-economic and cultural conditions. So, river canalisation increased the absorptive capacity against flooding, but at the cost of rapid water transfer downstream. Major water transportation projects were built to transfer water as well as ecosystem services from wet to dry areas, in order to increase socioeconomic resilience (Langridge et al., 2006). Hydraulic engineering was conducted to increase the system's absorptive capacity to cope with existing and known hazards (e.g. flooding, drought, and pollution). For example, damming was once regarded as one of the best solutions to avoid flooding and drought (Endfield, 2012; Ward, 2003). However, this improvement was at the expense of natural ecosystems and consequently decreased ecological adaptive capacity.

3. People and Water. Despite increasing capacities to manage water, societies face water supply crises amid the growing realisation that climate and global change are making this ever harder to address. For example, climate change may alter the prevailing hazard regime and put ecosystem services at risk, though it is not straightforward to know what the new regime and risks are. Thus, canalised rivers do not have the surplus capacity to absorb more frequent rain events or higher surface runoff, which leads to more severe flooding. Fernald et al. (2015) discovered that the traditional acequia systems may not still be tenable, when external drivers brought by climate and land-cover change push these systems beyond their historical limits. The spatial distribution of precipitation regimes may also be shifting under climate change, and this may turn regions from humid to dry, or vice versa (Collins et al., 2010), making water transportation projects redundant. These hard-engineering approaches generally have less flexibility and usually have a lengthier time lag in responding to change. The socio-hydrological system at this stage acts as a valuable heuristic for adaptive water management, offering the most resilient hydrological ecosystem services supply. The "People and Water" framing has shifted from the linear one-way relationship of "Water for People", to a multi-layered and multi- 
dimensional relationship between human societies and water systems (Mace, 2014).

We are now facing a new challenge of future water contingencies and uncertain water-related hazards, which was transited from the historical challenge of meeting the growing needs of hydrological ecosystem services. It implies that a shift of water strategies is urgently required. We argue that most current water management practices are now seeking to transition from resistant to resilient strategies (Gillson et al., 2013; Khamis et al., 2013; Fig. 5). From the perspective of a resilient socio-hydrological system, we believe that this strategy is not only needed for water management, but potentially offers a feasible alternative for achieving sustainable hydrological ecosystem service provision. Awareness of change suggests an increase in adaptive capacity, and implies that the pathway to socio-hydrological resilience will involve "soft" approaches that are complementary to engineeringbased methods (Park et al., 2013). This implies that interventions in all the source of resilience, including water and human subsystems and human-water interactions need to be considered. Some promising example approaches are provided as follows. Ecosystem restorations such as decanalisation, improving river connectivity, and floodplain recovery also suggest enhanced ecological or hydrological adaptability (Brauman et al., 2007), although in the process absorptive capacity may be compromised (Chen et al., 2016). This reemphasis on the ecosystem integrity in response to degrading environmental quality is also aligned with the "pendulum swing" phenomenon discussed by Kandasamy et al. (2014). Polycentric water governance and public participation in more centralised forms of decision-making may play important roles in building socio-hydrological resilience (Buytaert et al., 2014, 2016). Polycentric systems have multiple governance units on multiple scales, which provide the flexibility to deal with the target problems on appropriate scale, and offers institutional back-ups to respond to uncertainties (Andersson and Ostrom, 2008; Garmestani and Benson, 2013). In addition, technological innovations as well as advances in data collection and prediction models also contribute to improving socio-hydrological resilience, in both absorptive and adaptive ways (Karpouzoglou et al., 2016b). For example, the Environment Agency for England and Wales offers early-warning systems that provide forecasting and personalised household information, a practice which builds upon developing technologies and skills to map and measure risk (Environment Agency, 2009).

\section{Concluding remarks}

Evaluating resilience in a socio-hydrological context is challenging because of different framings of water-related resilience, including hydrological resilience to anthropogenic disturbances, social resilience to hydrological disasters, and socio-hydrological resilience. Although these reflect differ- ent aspects of human-water interactions, they are not easy to distinguish. To better conceptualise the linkage between resilience and socio-hydrology, we have emphasised the need to define the system type prior to discussing their intrinsic resilience and have argued that resilience be regarded as a set of systematic properties including absorptive, adaptive and transformative capacities. Based on this understanding, we have proposed a conceptual framework of humanwater couplings and resilience framings, including a heuristic approach to identifying possible pathways to resilience in socio-hydrological contexts.

Focusing on three coupling and framing types, we highlighted the potential of socio-hydrological resilience. If human societies are considered as endogenous components of water cycles, this newly proposed resilience concept is useful to answer how socio-hydrological systems respond to and cope with perturbations. On this basis, we have shown the utility and complementarity of resilience with ecosystem services, and argued that the framework of ecosystem services can be a promising tool to describe the resilient dynamics of socio-hydrological systems, since it reflects an essential aspect of the human-water interface.

Different types of resilience may match particular problems with knowledge and research traditions in certain academic fields. For example, hydrological resilience to human hazards may be usefully analysed with biophysical sciences for aquatic ecosystem conservation, while social resilience to hydrological hazards will require significant inputs from social sciences. It is important to consider the different nature of human and biophysical systems where different resilience approaches are used. For example, the ecologically oriented concept of resilience has received critiques when applied in human systems, because it oversimplifies the understanding of equilibria and feedbacks, ignores the importance of social conflict and power, and addresses the notion of system function which is not the key focus in social science (Olsson et al., 2015). This does not mean that resilience should be discarded as a concept. However, we should heed calls for pluralism, stimulate dialogue, and develop a clearer identity of resilience as applied in the socio-hydrological context (Cote and Nightingale, 2012; Cumming et al., 2005; Olsson et al., 2015).

Resilience is not only a descriptive notion and usually has normative (goal-setting) objectives. To build pathways to socio-hydrological resilience, we introduced the notion of the resilience canvas to compare absorptive and adaptive capacities. The resilience canvas can be used to design bespoke interventions and strategies for all types of humanwater couplings on different scales from single-river-basin to global level. On this canvas, we showed that the global sociohydrological system has moved from the stage in "People with Water", through the "Water for People" stage, towards the "People and Water" stage, along with people's growing demand on water and the increasing resilience of hydrological ecosystem services supply. Nonetheless there is still sub- 
stantial geographic variation globally in the distribution of these socio-hydrological stages.

Therefore, this new conceptual framework with the resilience canvas motivates some future work on resilience. For example, we need to review, compare, and classify existing resilience indicators, propose new quantification and assessment methods for different resilience framings, or even develop mathematical tools to quantitatively describe the resilient processes of the capacities (Gao et al., 2016). We also need to conceptualise resilience dynamics and pathways over time with empirical studies and shift resilience studies from focusing on single cases at particular points in time, to macro-scale comparisons between the past, present, and future. In addition, our argument provokes a rethinking of using resilience in other human-nature contexts, such as socialecological systems (Ostrom, 2009) and coupled human and natural systems (Liu et al., 2007). We suggest there is considerable potential to scrutinise the concept of resilience and better refine its identity and capacities in these systems. Similarly, different framings such as ecological resilience, social resilience to ecological hazards and social-ecological resilience can also be recognised; and within each framing, resilience as systematic properties can be viewed at the capacity level by using the resilience canvas. Hence, we argue that this conceptual framework can be used to guide and construct discourses of resilience in the human-nature context, so bringing greater conceptual rigour and clarity to bear on one of the most pressing contemporary public policy challenges of our time.

Data availability. No data sets were used in this article.

Author contributions. FM initialised the ideas of the paper with DH and JC. FM prepared the manuscript with contributions from all coauthors. Figures were prepared by FM.

Competing interests. The authors declare that they have no conflict of interest.

Acknowledgements. This paper was developed within the "Mountain-EVO: Towards a virtual observatory for ecosystem services and poverty alleviation" project, which is supported by the ESPA Project Framework grant (project code: NE/K010239-1). We thank all the project collaborators from Nepal, Peru, Kyrgyzstan, and Ethiopia, for fruitful discussions that facilitated the conception of ideas discussed herewith. We thank Kieran Khamis for his advice in selecting examples for the resilience canvas.There are no additional data associated with this conceptual paper.

Edited by: Hilary McMillan

Reviewed by: Anna Wesselink and one anonymous referee

\section{References}

Adger, W. N., Hughes, T. P., Folke, C., Carpenter, S. R., and Rockström, J.: Social-ecological resilience to coastal disasters, Science, 309, 1036-1039, 2005.

Aerts, J. C. J. H., Botzen, W. J. W., Emanuel, K., Lin, N., and De Moel, H.: Evaluating Flood Resilience Strategies for Coastal Megacities, Science, 344, 1-3, 2014.

Anderies, J. M., Janssen, M. A., and Ostrom, E.: A Framework to Analyze the Robustness of Social-Ecological Systems from an Institutional Perspective, Ecol. Soc., 9, 1-18, 2004.

Andersson, K. P. and Ostrom, E.: Analyzing decentralized resource regimes from a polycentric perspective, Policy Sci., 41, 71-93, 2008.

Arnall, A.: Resilience as transformative capacity: Exploring the quadripartite cycle of structuration in a Mozambican resettlement programme, Geoforum, 66, 26-36, 2015.

Backlund, A.: The definition of system, Kybernetes, 29, 444-451, 2000.

Barange, M., Merino, G., Blanchard, J. L., Scholtens, J., Harle, J., Allison, E. H., Allen, J. I., Holt, J., and Jennings, S.: Impacts of climate change on marine ecosystem production in societies dependent on fisheries, Nature Climate Change, 4, 211-216, 2014.

Barrett, C. B. and Constas, M. A.: Toward a theory of resilience for international development applications, P. Natl. Acad. Sci. USA, 111, 14625-14630, 2014.

Béné, C., Newsham, A., Davies, M., Ulrichs, M., and GodfreyWood, R.: Review article: Resilience, poverty and development, J. Int. Dev., 26, 598-623, 2014.

Bennett, N. J., Dearden, P., Murray, G., and Kadfak, A.: The capacity to adapt?: Communities in a changing climate, environment, and economy on the northern Andaman coast of Thailand, Ecol. Soc., 19, 5, 2014.

Biggs, R., Carpenter, S. R., and Brock, W. A.: Turning back from the brink: detecting an impending regime shift in time to avert it, P. Natl. Acad. Sci. USA, 106, 826-831, 2009.

Biggs, R., Schlüter, M., Biggs, D., Bohensky, E. L., BurnSilver, S., Cundill, G., Dakos, V., Daw, T. M., Evans, L. S., Kotschy, K., Leitch, A. M., Meek, C., Quinlan, A., Raudsepp-Hearne, C., Robards, M. D., Schoon, M. L., Schultz, L., and West, P. C.: Toward Principles for Enhancing the Resilience of Ecosystem Services, Annu. Rev. Environ. Resour., 37, 421-448, 2012.

Biggs, R., Schlüter, M., and Schoon, M. L. (Eds.): Principles for Building Resilience: Sustaining Ecosystem Services in SocialEcological Systems, Cambridge University Press, Cambridge, 2015.

Bisson, P. A., Dunham, J. B., and Reeves, G. H.: Freshwater ecosystems and resilience of Pacific salmon: habitat management based on natural variability, Ecol. Soc., 14, 45, 2009.

Botter, G., Basso, S., Rodriguez-Iturbe, I., and Rinaldo, A.: Resilience of river flow regimes, P. Natl. Acad. Sci. USA, 110, 12925-12930, 2013.

Brand, F. S. and Jax, K.: Focusing the Meaning(s) of Resilience?: Resilience as a Descriptive Concept and a Boundary Object, Ecol. Soc., 12, 23, 2007.

Brauman, K. A., Daily, G. C., Duarte, T. K., and Mooney, H. A.: The Nature and Value of Ecosystem Services: An Overview Highlighting Hydrologic Services, Annu. Rev. Environ. Resour., 32, 67-98, 2007. 
Bunn, S. E., Abal, E. G., Smith, M. J., Choy, S. C., Fellows, C. S., Harch, B. D., Kennard, M. J., and Sheldon, F.: Integration of science and monitoring of river ecosystem health to guide investments in catchment protection and rehabilitation, Freshwater Biol., 55, 223-240, 2010.

Buytaert, W., Zulkafli, Z., Grainger, S., Acosta, L., Alemie, T. C., Bastiaensen, J., De Bièvre, B., Bhusal, J., Clark, J., Dewulf, A., Foggin, M., Hannah, D. M., Hergarten, C., Isaeva, A., Karpouzoglou, T., Pandeya, B., Paudel, D., Sharma, K., Steenhuis, T., Tilahun, S., Van Hecken, G., and Zhumanova, M.: Citizen science in hydrology and water resources: opportunities for knowledge generation, ecosystem service management, and sustainable development, Front. Earth Sci., 2, 1-21, 2014.

Buytaert, W., Dewulf, A., De Bièvre, B., Clark, J., and Hannah, D. M.: Citizen Science for Water Resources Management: Toward Polycentric Monitoring and Governance?, J. Water Resour. Plan. Manag., 142, 1816002, https://doi.org/10.1061/(ASCE)WR.1943-5452.0000641, 2016.

Carey, M., Baraer, M., Mark, B. G., French, A., Bury, J., Young, K. R., and McKenzie, J. M.: Toward hydro-social modeling: Merging human variables and the social sciences with climate-glacier runoff models (Santa River, Peru), J. Hydrol., 518, 60-70, 2014.

Carpenter, K. E., Abrar, M., Aeby, G., Aronson, R. B., Banks, S., Bruckner, A., Chiriboga, A., Cortes, J., Delbeek, J. C., DeVantier, L., Edgar, G. J., Edwards, A. J., Fenner, D., Guzman, H. M., Hoeksema, B. W., Hodgson, G., Johan, O., Licuanan, W. Y., Livingstone, S. R., Lovell, E. R., Moore, J. A., Obura, D. O., Ochavillo, D., Polidoro, B. A., Precht, W. F., Quibilan, M. C., Reboton, C., Richards, Z. T., Rogers, A. D., Sanciangco, J., Sheppard, A., Sheppard, C., Smith, J., Stuart, S., Turak, E., Veron, J. E. N., Wallace, C., Weil, E., and Wood, E.: One-Third of Reef-Building Corals Face Elevated Extinction Risk from Climate Change and Local Impacts, Science, 321, 560-563, 2008.

Carpenter, S., Walker, B., Anderies, J. M., and Abel, N.: From metaphor to measurement: Resilience of what to what?, Ecosystems, 4, 765-781, 2001.

Chen, X., Wang, D., Tian, F., and Sivapalan, M.: From channelization to restoration: Sociohydrologic modeling with changing community preferences in the Kissimmee River Basin, Florida, Water Resour. Res., 51, 1-18, 2016.

Collins, M., An, S.-I., Cai, W., Ganachaud, A., Guilyardi, E., Jin, F.-F., Jochum, M., Lengaigne, M., Power, S., Timmermann, A., Vecchi, G., and Wittenberg, A.: The impact of global warming on the tropical Pacific Ocean and El Nino, Nat. Geosci., 3, 391-397, 2010.

Cote, M. and Nightingale, A. J.: Resilience thinking meets social theory: Situating social change in socio-ecological systems (SES) research, Prog. Hum. Geogr., 36, 475-489, 2012.

Crane, T. A.: Of models and meanings: Cultural resilience in socialecological systems, Ecol. Soc., 15, 19, 2010.

Cumming, G. S., Barnes, G., Perz, S., Schmink, M., Sieving, K. E., Southworth, J., Binford, M., Holt, R. D., Stickler, C., and Van Holt, T.: An exploratory framework for the empirical measurement of resilience, Ecosystems, 8, 975-987, 2005.

Cutter, S. L., Barnes, L., Berry, M., Burton, C., Evans, E., Tate, E., and Webb, J.: A place-based model for understanding community resilience to natural disasters, Global Environ. Chang., 18, 598-606, 2008.
Cutter, S. L., Burton, C. G., and Emrich, C. T.: Disaster Resilience Indicators for Benchmarking Baseline Conditions, J. Homel. Secur. Emerg. Manag., 7, 1-22, 2010.

Czucz, B., Csecserits, A., Botta-Dukat, Z., Kroel-Dulay, G., Szabo, R., Horvath, F., and Molnar, Z.: An indicator framework for the climatic adaptive capacity of natural ecosystems, J. Veg. Sci., 22, 711-725, 2011.

Daily, G. C., Polasky, S., Goldstein, J., Kareiva, P. M., Mooney, H. A., Pejchar, L., Ricketts, T. H., Salzman, J., and Shallenberger, R.: Ecosystem services in decision making: time to deliver, Front. Ecol. Environ., 7, 21-28, 2009.

da Silveira, A. R. and Richards, K. S.: The Link Between Polycentrism and Adaptive Capacity in River Basin Governance Systems: Insights from the River Rhine and the Zhujiang (Pearl River) Basin, Ann. Assoc. Am. Geogr., 103, 319-329, 2013.

Davoudi, S., Shaw, K., Haider, L. J., Quinlan, A. E., Peterson, G. D., Wilkinson, C., Fünfgeld, H., McEvoy, D., and Porter, L.: Resilience: A Bridging Concept or a Dead End? "Reframing" Resilience: Challenges for Planning Theory and Practice Interacting Traps: Resilience Assessment of a Pasture Management System in Northern Afghanistan Urban Resilience: What Does it Mean in Planni, Plan. Theory Pract., 13, 299-333, 2012.

Dawson, T. P., Jackson, S. T., House, J. I., Prentice, I. C., and Mace, G. M.: Beyond predictions: biodiversity conservation in a changing climate, Science, 332, 53-58, https://doi.org/10.1126/science.1200303, 2011.

de Groot, R. S., Wilson, M. A., and Boumans, R. M. J.: A typology for the classification, description and valuation of ecosystem functions, goods and services, Ecol. Econ., 41, 393-408, 2002.

Dent, C. L., Cumming, G. S., and Carpenter, S. R.: Multiple states in river and lake ecosystems, Philos. T. R. Soc. Lon. B, 357, 635645, 2002.

Doney, S. C., Ruckelshaus, M., Duffy, J. E., Barry, J. P., Chan, F., English, C. A., Galindo, H. M., Grebmeier, J. M., Hollowed, A. B., Knowlton, N., Polovina, J., Rabalais, N. N., Sydeman, W. J., and Talley, L. D.: Climate change impacts on marine ecosystems, Ann. Rev. Mar. Sci., 4, 11-37, 2012.

Dudgeon, D., Arthington, A. H., Gessner, M. O., Kawabata, Z. I., Knowler, D. J., Leveque, C., Naiman, R. J., PrieurRichard, A. H., Soto, D., Stiassny, M. L. J., and Sullivan, C. A.: Freshwater biodiversity: importance, threats, status and conservation challenges, Biol. Rev., 81, 163-182, https://doi.org/10.1017/S1464793105006950, 2006.

Dufour, S. and Piégay, H.: From the myth of a lost paradise to targeted river restoration: forget natural references and focus on human benefits, River Res. Appl., 25, 568-581, 2009.

Elshafei, Y., Sivapalan, M., Tonts, M., and Hipsey, M. R.: A prototype framework for models of socio-hydrology: identification of key feedback loops and parameterisation approach, Hydrol. Earth Syst. Sci., 18, 2141-2166, https://doi.org/10.5194/hess-182141-2014, 2014.

Endfield, G. H.: The resilience and adaptive capacity of socialenvironmental systems in colonial Mexico, P. Natl. Acad. Sci USA, 109, 3676-3681, 2012.

Engel, S. and Schaefer, M.: Ecosystem services-a useful concept for addressing water challenges?, Curr. Opin. Environ. Sustain., 5, 696-707, 2013.

Engle, N. L.: Adaptive capacity and its assessment, Global Environ. Chang., 21, 647-656, 2011. 
Environment Agency: A National Assessment of Flood Risk, Flooding Engl., 36, 2009.

Ernstson, H., Van Der Leeuw, S. E., Redman, C. L., Meffert, D. J., Davis, G., Alfsen, C., and Elmqvist, T.: Urban transitions: On urban resilience and human-dominated ecosystems, Ambio, 39, 531-545, 2010.

Evans, B. and Reid, J.: Dangerously exposed: the life and death of the resilient subject, Resilience, 1, 83-98, 2013.

Fernald, A., Guldan, S., Boykin, K., Cibils, A., Gonzales, M., Hurd, B., Lopez, S., Ochoa, C., Ortiz, M., Rivera, J., Rodriguez, S., and Steele, C.: Linked hydrologic and social systems that support resilience of traditional irrigation communities, Hydrol. Earth Syst. Sci., 19, 293-307, https://doi.org/10.5194/hess-19293-2015, 2015.

Few, R., Brown, K., and Tompkins, E. L.: Public participation and climate change adaptation: avoiding the illusion of inclusion, Clim. Policy, 7, 46-59, 2007.

Folke, C.: Resilience (Republished), Ecol. Soc., 21, 44, https://doi.org/10.5751/ES-09088-210444, 2016.

Folke, C., Hahn, T., Olsson, P., and Norberg, J.: Adaptive Governance of Social-Ecological Systems, Annu. Rev. Environ. Resour., 30, 441-473, 2005.

Folke, C., Carpenter, S. R., Walker, B., Scheffer, M., Chapin, T., and Rockström, J.: Resilience thinking: Integrating resilience, adaptability and transformability, Ecol. Soc., 15, 62-68, 2010.

Gallopín, G. C.: Linkages between vulnerability, resilience, and adaptive capacity, Global Environ. Chang., 16, 293-303, 2006.

Gao, J., Barzel, B., and Barabási, A.-L.: Universal resilience patterns in complex networks, Nature, 530, 307-312, 2016.

Garmestani, A. S. and Benson, M. H.: A framework for resiliencebased governance of social-ecological systems, Ecol. Soc., 18, 9, https://doi.org/10.5751/ES-05180-180109, 2013.

Gibbs, M. T.: Resilience: What is it and what does it mean for marine policymakers?, Mar. Policy, 33, 322-331, 2009.

Gillson, L., Dawson, T. P., Jack, S., and McGeoch, M. A.: Accommodating climate change contingencies in conservation strategy, Trends Ecol. Evol., 28, 135-142, 2013.

Gleick, P. H.: Facing Down the Hydro-Crisis, World Policy J., 26, 17-23, 2009.

Gleick, P. H. and MacDonald, G. M.: Roadmap for sustainable water resources in southwestern North America, P. Natl. Acad. Sci. USA, 107, 21300-21305, 2010.

Gómez-Baggethun, E., Reyes-García, V., Olsson, P., and Montes, C.: Traditional ecological knowledge and community resilience to environmental extremes: A case study in Doñana, SW Spain, Global Environ. Chang., 22, 640-650, 2012.

Gupta, J., Termeer, C., Klostermann, J., Meijerink, S., van den Brink, M., Jong, P., Nooteboom, S., and Bergsma, E.: The Adaptive Capacity Wheel: A method to assess the inherent characteristics of institutions to enable the adaptive capacity of society, Environ. Sci. Policy, 13, 459-471, 2010.

Haasnoot, M., Kwakkel, J. H., Walker, W. E., and ter Maat, J.: Dynamic adaptive policy pathways: A method for crafting robust decisions for a deeply uncertain world, Global Environ. Chang., 23, 485-498, 2013.

Hallegatte, S., Green, C., Nicholls, R. J., and Corfee-Morlot, J.: Future flood losses in major coastal cities, Nature Climate Change, 3, 802-806, 2013.
Harder, P., Pomeroy, J. W., and Westbrook, C. J.: Hydrological resilience of a Canadian Rockies headwaters basin subject to changing climate, extreme weather, and forest management, Hydrol. Process., 29, 3905-3924, 2015.

Hickey, M. B. C. and Doran, B.: A review of the efficiency of buffer strips for the maintenance and enhancement of riparian ecosystems, Water Qual. Res. J. Canada, 39, 311-317, 2004.

Hoegh-Guldberg, O. and Bruno, J. F.: The Impact of Climate Change on the World's Marine Ecosystems, Science, 328, 15231528, 2010.

Hoegh-Guldberg, O., Mumby, P. J., Hooten, A. J., Steneck, R. S., Greenfield, P., Gomez, E., Harvell, C. D., Sale, P. F., Edwards, A. J., Caldeira, K., Knowlton, N., Eakin, C. M., Iglesias-Prieto, R., Muthiga, N., Bradbury, R. H., Dubi, A., and Hatziolos, M. E.: Coral Reefs under Rapic Climate Change and Ocean Acidification, Science, 318, 1737-1742, 2008.

Hoffmann, A. and Sgrò, C.: Climate change and evolutionary adaptation, Nature, 470, 479-485, 2011.

Holling, C. S.: Resilience and stability of ecological systems, Annu. Rev. Ecol. Syst., 4, 1-23, 1973.

Josefsson, H. and Baaner, L.: The Water Framework Directive A Directive for the Twenty-First Century?, J. Environ. Law, 23, 463-486, 2011.

Kandasamy, J., Sounthararajah, D., Sivabalan, P., Chanan, A., Vigneswaran, S., and Sivapalan, M.: Socio-hydrologic drivers of the pendulum swing between agricultural development and environmental health: a case study from Murrumbidgee River basin, Australia, Hydrol. Earth Syst. Sci., 18, 1027-1041, https://doi.org/10.5194/hess-18-1027-2014, 2014.

Karpouzoglou, T., Dewulf, A., and Clark, J.: Advancing adaptive governance of social-ecological systems through theoretical multiplicity, Environ. Sci. Policy, 57, 1-9, 2016 a.

Karpouzoglou, T., Zulkafli, Z., Grainger, S., Dewulf, A., Buytaert, W., and Hannah, D. M.: Environmental Virtual Observatories (EVOs): prospects for knowledge co-creation and resilience in the Information Age, Curr. Opin. Environ. Sustain., 18, 40-48, $2016 b$.

Keating, K., May, P., Pettit, A., and Pickering, R.: Cost estimation for household flood resitance and resilience measures - summary of evidence, Report - SC080039/R11, 28, 2015.

Keck, M. and Sakdapolrak, P.: What is social resilience? Lessons learned and ways forward, Erdkunde, 67, 5-19, 2013.

Kelman, I., Gaillard, J. C., and Mercer, J.: Climate Change's Role in Disaster Risk Reduction's Future: Beyond Vulnerability and Resilience, Int. J. Disaster Risk Sci., 6, 21-27, 2015.

Khamis, K., Hannah, D. M., Hill Calvis, M., Brown, L. E., Castella, E., and Milner, A. M.: Alpine aquatic ecosystem conservation policy in a changing climate, Environ. Sci. Policy, 43, 39-55, 2013.

Klein, R. J. T., Nicholls, R. J., and Thomalla, F.: Resilience to natural hazards: How useful is this concept?, Environ. Hazards, 5, 35-45, 2003.

Krimbas, C. B.: On fitness, Biol. Philos., 19, 185-203, 2004.

Kumar, P.: Hydrocomplexity: Addressing water security and emergent environmental risks, Water Resour. Res., 51, 5827-5838, 2015.

Kuo, C.-Y., Yuen, Y. S., Meng, P.-J., Ho, P.-H., Wang, J.-T., Liu, P.J., Chang, Y.-C., Dai, C.-F., Fan, T.-Y., Lin, H.-J., Baird, A. H., and Chen, C. A.: Recurrent Disturbances and the Degradation 
of Hard Coral Communities in Taiwan, PLoS One, 7, e44364, https://doi.org/10.1371/journal.pone.0044364, 2012.

Langridge, R., Christian-Smith, J., and Lohse, K. A.: Access and resilience: Analyzing the construction of social resilience to the threat of water scarcity, Ecol. Soc., 11, 18, 2006.

Liao, K. H.: A theory on urban resilience to floods - A basis for alternative planning practices, Ecol. Soc., 17, 48, https://doi.org/10.5751/ES-05231-170448, 2012.

Limburg, K. E., O’Neill, R. V., Costanza, R., and Farber, S.: Complex systems and valuation, Ecol. Econ., 41, 409-420, 2002.

Lindner, M., Maroschek, M., Netherer, S., Kremer, A., Barbati, A., Garcia-Gonzalo, J., Seidl, R., Delzon, S., Corona, P., Kolström, M., Lexer, M. J., and Marchetti, M.: Climate change impacts, adaptive capacity, and vulnerability of European forest ecosystems, Forest Ecol. Manage., 259, 698-709, 2010.

Linton, J. and Budds, J.: The hydrosocial cycle: Defining and mobilizing a relational-dialectical approach to water, Geoforum, 57, 170-180, 2014.

Liu, J., Dietz, T., Carpenter, S. R., Alberti, M., Folke, C., Moran, E., Pell, A. N., Deadman, P., Kratz, T., Lubchenco, J., Ostrom, E., Ouyang, Z., Provencher, W., Redman, C. L., Schneider, S. H., and Taylor, W. W.: Complexity of coupled human and natural systems, Science, 317, 1513-1516, 2007.

Lorenz, D. F.: The diversity of resilience: Contributions from a social science perspective, Nat. Hazards, 67, 7-24, 2013.

Mace, G. M.: Whose conservation? Changes in the perception and goals of nature conservation require a solid scientific basis, Science, 245, 1558-1560, 2014.

MacKinnon, D. and Derickson, K. D.: From resilience to resourcefulness: A critique of resilience policy and activism, Prog. Hum. Geogr., 37, 253-270, 2012.

Malhotra, S., Kim, T., Zager, J., Bennett, J., Ebright, M., D'Angelica, M., and Fong, Y.: Use of an oncolytic virus secreting GM-CSF as combined oncolytic and immunotherapy for treatment of colorectal and hepatic adenocarcinomas, Surgery, 141, 520-529, 2007.

Mao, F. and Richards, K.: Irreversible river water quality and the concept of the reference condition, Area, 44, 423-431, 2012.

McGlade, J., McIntosh, B. S., and Jeffrey, P.: Landscape Sensitivity, Resilience and Sustainable Watershed Management, in: Coping with Water Deficiency: From Research to Policymaking With Examples from Southern Europe, the Mediterranean and Developing Countries, edited by: Koundouri, P., 23 pp., Springer Netherlands, 2008.

Meerow, S., Newell, J. P., and Stults, M.: Defining urban resilience?: A review, Landsc. Urban Plan., 147, 38-49, 2016.

Methmann, C. and Oels, A.: From "fearing" to "empowering" climate refugees: Governing climate-induced migration in the name of resilience, Secur. Dialogue, 46, 51-68, 2015.

Millennium Ecosystem Assessment: Ecosystems and human wellbeing: Synthesis, Island Press, Washington, DC, 2005.

Miller, F., Osbahr, H., Boyd, E., Thomalla, F., Bharwani, S., Ziervogel, G., Walker, B., Birkmann, J., van der Leeuw, S., Rockström, J., Hinkel, J., Downing, T., Folke, C., and Nelson, D.: Resilience and vulnerability: Complementary or conflicting concepts, Ecol. Soc., 15, 11, 2011.

Miller, S. W., Wooster, D., and Li, J.: Resistance and resilience of macroinvertebrates to irrigation water withdrawals, Freshwater Biol., 52, 2494-2510, 2007.
Milman, A. and Short, A.: Incorporating resilience into sustainability indicators: An example for the urban water sector, Global Environ. Chang., 18, 758-767, 2008.

Montanari, A., Young, G., Savenije, H. H. G., Hughes, D., Wagener, T., Ren, L. L., Koutsoyiannis, D., Cudennec, C., Toth, E., Grimaldi, S., Blöschl, G., Sivapalan, M., Beven, K., Gupta, H., Hipsey, M., Schaefli, B., Arheimer, B., Boegh, E., Schymanski, S. J., Di Baldassarre, G., Yu, B., Hubert, P., Huang, Y., Schumann, A., Post, D. A., Srinivasan, V., Harman, C., Thompson, S., Rogger, M., Viglione, A., McMillan, H., Characklis, G., Pang, Z., and Belyaev, V.: "Panta Rhei - Everything Flows": Change in hydrology and society - The IAHS Scientific Decade 2013-2022, Hydrol. Sci. J., 58, 1256-1275, 2013.

National Research Council: Resilience and Ecosystem Services, in: An Ecosystem Services Approach to Assessing the Impacts of the Deepwater Horizon Oil Spill in the Gulf of Mexico, 246 pp., https://doi.org/10.17226/18387, National Academies Press, 2013.

Norris, F. H., Stevens, S. P., Pfefferbaum, B., Wyche, K. F., and Pfefferbaum, R. L.: Community resilience as a metaphor, theory, set of capacities, and strategy for disaster readiness, Am. J. Community Psychol., 41, 127-150, 2008.

Olsson, L., Jerneck, A., Thoren, H., Persson, J., and O'Byrne, D.: Why resilience is unappealing to social science: Theoretical and empirical investigations of the scientific use of resilience, Sci. Adv., 1, e1400217, https://doi.org/10.1126/sciadv.1400217, 2015.

O'Reilly, C. M., Alin, S. R., Plisnier, P.-D. D., Cohen, A. S., and McKee, B. A.: Climate change decreases aquatic ecosystem productivity of Lake Tanganyika, Africa, Nature, 424, 766-768, 2003.

Ostadtaghizadeh, A., Ardalan, A., Paton, D., Jabbari, H., and Khankeh, H. R.: Community Disaster Resilience: a Systematic Review on Assessment Models and Tools, PLoS Curr. Disasters, 1-14, https://doi.org/10.1371/currents.dis. f224ef8efbdfcf1d508dd0de4d8210ed, 2015.

Ostrom, E.: A general framework for analyzing sustainability of social-ecological systems, Science, 325, 419-422, 2009.

Ozkan, K., Jeppesen, E., Johansson, L. S., and Beklioglu, M.: The response of periphyton and submerged macrophytes to nitrogen and phosphorus loading in shallow warm lakes: A mesocosm experiment, Freshwater Biol., 55, 463-475, 2010.

Pahl-Wostl, C.: A conceptual framework for analysing adaptive capacity and multi-level learning processes in resource governance regimes, Global Environ. Chang., 19, 354-365, 2009.

Pahl-Wostl, C., Vorosmarty, C., Bhaduri, A., Bogardi, J., Rockstrom, J., and Alcamo, J.: Towards a sustainable water future: Shaping the next decade of global water research, Curr. Opin. Environ. Sustain., 5, 708-714, 2013.

Park, J., Seager, T. P., Rao, P. S. C., Convertino, M., and Linkov, I.: Integrating risk and resilience approaches to catastrophe management in engineering systems, Risk Anal., 33, 356-367, 2013.

Pearson, R. G.: Reasons to Conserve Nature, Trends Ecol. Evol., 31, 366-371, 2016.

Peterson, T. J., Western, A. W., and Argent, R. M.: Analytical methods for ecosystem resilience: A hydrological investigation, Water Resour. Res., 48, 1-16, 2012.

Plummer, R. and Armitage, D.: A resilience-based framework for evaluating adaptive co-management: Linking ecology, eco- 
nomics and society in a complex world, Ecol. Econ., 61, 62-74, 2007.

Robinson, G. M. and Carson, D. A.: Resilient communities: Transitions, pathways and resourcefulness, Geogr. J., 182, https://doi.org/10.1111/geoj.12144, 2015.

Rockström, J., Falkenmark, M., Folke, C., Lannerstad, M., Barron, J., Enfors, E., Gordon, L., Heinke, J., Hoff, H., and Pahl-Wostl, C.: Water resilience for human prosperity, Water Resil. Hum. Prosper., 1784, 1-292, 2014.

Sala, O. E., Chapin, F. S., Armesto, J. J., Berlow, E., Bloomfield, J., Dirzo, R., Huber-Sanwald, E., Huenneke, L. F., Jackson, R. B., Kinzig, A., Leemans, R., Lodge, D. M., Mooney, H. A., Oesterheld, M., Poff, N. L., Sykes, M. T., Walker, B. H., Walker, M., and Wall, D. H.: Global Biodiversity Scenarios for the Year 2100, Science, 287, 1770-1774, 2000.

Scheffer, M., Carpenter, S., Foley, J. A., Folke, C., and Walker, B.: Catastrophic shifts in ecosystems, Nature, 413, 591-596, 2001.

Scheffer, M., Barrett, S., Carpenter, S. R., Folke, C., Green, A. J., Holmgren, M., Hughes, T. P., Kosten, S., van de Leemput, I. A., Nepstad, D. C., van Nes, E. H., Peeters, E. T. H. M., and Walker, B.: Creating a safe operating space for iconic ecosystems, Science, 347, 1317-1319, 2015.

Sivakumar, B.: Socio-hydrology: Not a new science, but a recycled and re-worded hydrosociology, Hydrol. Process., 26, 3788-3790, 2012.

Sivapalan, M., Savenije, H. H. G., and Blöschl, G.: Sociohydrology: A new science of people and water, Hydrol. Process., 26, 1270-1276, 2012.

Sivapalan, M., Konar, M., and Srinivasan, V.: Socio-hydrology: Use-inspired water sustainability science for the Anthropocene Earth's Future, Earth's Futur., 2, 225-230, 2014.

Smit, B. and Wandel, J.: Adaptation, adaptive capacity and vulnerability, Global Environ. Chang., 16, 282-292, 2006.

Strunz, S.: Is conceptual vagueness an asset? Arguments from philosophy of science applied to the concept of resilience, Ecol. Econ., 76, 112-118, 2012.

Sudmeier-Rieux, K. I.: Resilience - an emerging paradigm of danger or of hope?, Disaster Prev. Manag., 23, 67-80, 2014.

Terrado, M., Acuña, V., Ennaanay, D., Tallis, H., and Sabater, S.: Impact of climate extremes on hydrological ecosystem services in a heavily humanized Mediterranean basin, Ecol. Indic., 37, 199-209, 2014.

Thomas, D. S. G. (Ed.): The Dictionary of Physical Geography, Fourth Edn., Wiley-Blackwell, Hoboken, NJ, 2016.

Turner, B. L., Kasperson, R. E., Matson, P. A., McCarthy, J. J., Corell, R. W., Christensen, L., Eckley, N., Kasperson, J. X., Luers, A., Martello, M. L., Polsky, C., Pulsipher, A., and Schiller, A.: A framework for vulnerability analysis in sustainability science, P. Natl. Acad. Sci. USA, 100, 8074-8079, 2003.

Van Loon, A. F., Stahl, K., Di Baldassarre, G., Clark, J., Rangecroft, S., Wanders, N., Gleeson, T., Van Dijk, A. I. J. M., Tallaksen, L. M., Hannaford, J., Uijlenhoet, R., Teuling, A. J., Hannah, D. M., Sheffield, J., Svoboda, M., Verbeiren, B., Wagener, T., and Van Lanen, H. A. J.: Drought in a humanmodified world: reframing drought definitions, understanding, and analysis approaches, Hydrol. Earth Syst. Sci., 20, 36313650, https://doi.org/10.5194/hess-20-3631-2016, 2016. van Vliet, M. T. H., Ludwig, F., and Kabat, P.: Global streamflow and thermal habitats of freshwater fishes under climate change, Climatic Change, 121, 739-754, 2013.

Vigerstol, K. L. and Aukema, J. E.: A comparison of tools for modeling freshwater ecosystem services, J. Environ. Manage., 92, 2403-2409, 2011.

Vorosmarty, C. J., Green, P., Salisbury, J., and Lammers, R. B.: Global Water Resources: Vulnerability from Climate Change and Population Growth, Science, 289, 284-288, 2000.

Walker, B., Hollin, C. S., Carpenter, S. R., Kinzig, A., Holling, C., Carpenter, S. R., and Kinzig, A.: Resilience, adaptability and transformability in social-ecological systems, Ecol. Soc., 9, 5, 2004.

Walker, B. H., Abel, N., Anderies, J. M., and Ryan, P.: Resilience, adaptability, and transformability in the Goulburn-Broken Catchment, Australia, Ecol. Soc., 14, 12, 2009.

Walker, B. H., Carpenter, S. R., Rockstrom, J., Crépin, A.S., and Peterson, G. D.: Drivers, "Slow" Variables, "Fast" Variables, Shocks, and Resilience, Ecol. Soc., 17, 30, https://doi.org/10.5751/ES-05063-170330, 2012.

Ward, D. R.: Water Wars: Drought, Flood, Folly and the Politics of Thirst, Riverhead Books, New York, 320 pp., 2003.

Weichselgartner, J. and Kelman, I.: Geographies of resilience?: Challenges and opportunities of a descriptive concept, Prog. Hum. Geogr., 39, 249-267, 2015.

Wesselink, A., Kooy, M., and Warner, J.: Socio-hydrology and hydrosocial analysis: toward dialogues across disciplines, Wiley Interdiscip. Rev. Water, 1-14, https://doi.org/10.1002/wat2.1196, November 2016.

West, S., Haider, J., Sinare, H., and Karpouzoglou, T.: Beyond divides: Prospects for synergy between resilience and pathways approaches to sustainability, STEPS Working Paper 65, STEPS Centre, Brighton, 2014.

Willis, K. J., Bailey, R. M., Bhagwat, S. A., and Birks, H. J. B.: Biodiversity baselines, thresholds and resilience: testing predictions and assumptions using palaeoecological data, Trends Ecol. Evol., 25, 583-591, 2010.

Wilson, S., Pearson, L. J., Kashima, Y., Lusher, D., and Pearson, C.: Separating adaptive maintenance (Resilience) and transformative capacity of social-ecological systems, Ecol. Soc., 18, 22, https://doi.org/10.5751/ES-05100-180122, 2013.

Wyborn, C.: Co-productive governance: A relational framework for adaptive governance, Global Environ. Chang., 30, 56-67, 2015.

Yan, L. and Xu, X.: Assessing the vulnerability of socialenvironmental system from the perspective of hazard, sensitivity, and resilience: A case study of Beijing, China, Environ. Earth Sci., 61, 1179-1186, 2010.

Zedler, J.: Progress in wetland restoration ecology, Trends Ecol. Evol., 15, 402-407, 2000. 